\title{
Toy planes
}

Time to leave.

\section{Tobias S. Buckell}

My sister Joanie's deft hands flicked from dreadlock to dreadlock, considering her strategy. "You always leaving," she said, flicking the razor on, and suddenly I'm five, chasing her with a kite made from plastic bags and twigs, shouting that I was going to fly away from her one day.

"I'm sorry. Please, let's get this done."

I'd waited long enough. I'd grown dreads because when I studied in the United States I wanted to remember who I was and where I came from as I began to lose my Caribbean accent. But the rocket plane's sponsor wanted them cut. It would be disaster for a helmet not to have a proper seal in an emergency. Explosive decompression was not something a soda company wanted to be associated with in their customers' minds. It was insulting that they assumed we couldn't keep the craft sealed. But we needed their money. The locks had become enough a part of me that I winced when the dippers bit into them, groaned, and another piece of me fell away.

In the back of the bus that I had pick me up, I hung on to a looped handle swinging from the roof as the driver rocketed down the dirt road from Joanie's. My sister had found a place out in the country, a nice concrete house with a basement opening up into a sloped garden on the side of a steep hill She taught mathematics at the school a few miles away, an open-shuttered building, and this would have been my future too, if I hadn't been so intent on 'getting off the rock.'

The islands always called their children back.

We hit asphalt, potholes, and passed cane fields with machete-wielding labourers hacking away at the stalks, sweatdrenched shirts knotted around their waists. It was hot; my arms stuck to the plastic covered seats. The driver leaned into a turn, and looked back. ${ }^{\text {I I want ask }}$ you something." I really wished the back seats had belts.

"Sure."

"All that money you spending, you don't think it better spent on getting better roads?" ${ }^{n e}$ dodged a pothole. "Or more school funding?"

Colourful red and yellow houses on stilts dotted the steep lush green mountainsides as I looked out of the tinted windows. "Only one small part of the programme got funded by the government," I explained. "We found private investors, advertisers, to back the rest. Whatever the government invested will be repaid."

"Maybe."

I had my extra arguments. How many people lived on this island? Tens of thousands. Most of our food was imported, leav-

in front of it I was five years old again, with no money, and a piece of scrap metal in the triangular shape of a space plane. I would pretend it was just like the real life ones I'd read about in the books donated to the school after the hurricane. And at night, when the power would sometimes flicker out, I'd go out and stand on the porch and look up at the bright stars and envy them.

The stall had a small bottle, hammered over with soda-can metal, with triangular welded-on wings, and a cone stuck to the back. It was painted over in yellow, black and green, and I bought it.

The rest of the day was a blur. Getting to the field involved running the press: yes I'd cut my hair for 'safety' reasons, yes I thought this was a good use of our money, not just first-world nations deserved space, it was there for everyone.

There were photos of me getting aboard the tiny rocket plane with a small brown package under my arm. The giant balloon platform that the plane hung from shifted in the gentle, salty island breeze. Not too far away the waves hit the sand of the beach. Inside, suited up, door closed, everything became electronic.

It was the cheapest way to get to orbit. Balloon up on a

ing us dependent on other food-producing nations, who all used satellites to track their farming. What spin-offtechnologies might come out of studying recycling in space? Why wait for other nations to get to it first? Research always produced good things for the people who engaged in it.

But I was tired of arguing for it, and I had only sound bites for him, the same ones I'd given the media who treated us like kids trying to do something all grown up.

The market surrounded me in a riot of colour: fruit, vegetables, full women in dresses in bright floral patterns. And the noise of hundreds constantly bargaining over things like the price of fish. Teenagers stood around the corners with friends. I wandered around looking for something, as we needed to fill the craft with enough extra weight to simulate a passenger and we still had a few extra ounces to add.

I found a small toy stall. And standing triangular platform to save on fuel, then light the rocket-plane up and head for orbit. We'd scavenged balloons and material from several companies, one about to go out of business. The plane chassis had once been used by a Chinese corporation during trials, and the guidance systems were all open-source. Online betting parlours had our odds at $50 \%$. We weren't even the first, but we were the first island.

The countdown finished, my stomach lurched, and I saw palm trees slide by the portholes to my right. I reached back and patted the package, the hammeredtogether toy, and smiled.

"Hello out there, all of you," I whispered into the radio. "We're coming up too."

Tobias S. Buckell is a Caribbean-born speculative fiction writer who now lives in Ohio. His first novel, Orystal Rain, will be out from Tor Books in February 2006. For more, seehis website: www.TobiasBuckell.com. 